\title{
The geographies of political ecology: after Edward Said
}

\author{
Joel Wainwright \\ Department of Geography, University of British Columbia, 1984 West Mall, Vancouver, \\ BC V6T 1Z2, Canada; e-mail: jdw@geog.ubc.ca \\ Received 28 May 2004; in revised form 3 September 2004
}

\begin{abstract}
This paper offers theoretical reflections on a series of questions raised by the shift in political ecology from the Third World to the First: what precisely constitutes a context for political ecology? How does something come to be a space or region that calls for political ecology? To respond to these questions, I argue for a turn to the thought of Edward Said, who articulates a Gramscian approach to geography that calls into question the constitution of the world.
\end{abstract}

"Just as none of us is outside or beyond geography, none of us is completely free from the struggle over geography."

Edward Said (1994 [1993], page 7)

Until recently, most political ecologists studied environmental conflict and change in communities in Latin America, Africa, and Asia. The field of knowledge this research produced was often referred to as 'Third world political ecology' (Bryant, 1997). This has changed with the publication of a number of new studies on environmental conflicts in industrial societies, particularly in the USA, Canada, and Europe. Recent works have examined the political ecology of the production and transformation of wetlands in Minnesota and Illinois (Robertson, 2000; 2004), forests (Prudham, 2003; 2004) and federal lands in the West (McCarthy, 2001; 2002), and the American lawn (Robbins and Sharp, 2003a; 2003b). And although it is not framed as a work in 'First World political ecology', we could include Mike Davis's (2003) brilliant collection of apocalyptic essays on late capitalist US urban ecologies in this genre.

This shift - both towards industrial economies and North American landscapespromises to advance the field in three ways. First, the study of industrial environments expands political ecology's purview into problems that are responsible for the some of the world's gravest ecological changes. Second, the shift from the Third World to the First complicates the narrative of early political ecology (compare Blaikie and Brookfield, 1987), because studies of environmental change and governance in industrial societies complicate notions of marginality, land management, and the place of nature (Wilson, 1999). Third, the shift opens up new questions about the relationships between spatiality, regions, and the ways we frame and interpret environmental conflicts. For these reasons, the call is out to produce a First World political ecology that takes the best of what has been done elsewhere and brings it 'home'. Nothing appears likely to stop this trend. As Paul Robbins (2002, page 1510) argues, there is "nothing about the epistemology, methodology, philosophy, or politics of Third World political ecology that bars its deployment in other contexts."

Perhaps this is true. And I have no strong objections to the proliferation of such research. Yet I wonder if there is something ontological that Robbins may have left off his list. Perhaps what should 'bar its deployment' - or at least prompt a hesitation on our part to celebrate the shift of political ecology from the Third to the First World - is a line of questions about the relationship between political ecology and its spaces of analysis: what precisely constitutes a 'context' of, and for, political ecology? How does 
something come to be a space or region that calls for political ecology? How do we know where the context of our research lies? Is the inquiry into this knowledge itself part of doing political ecology?

This essay offers some reflections on these questions. My aim is to think through some of the conditions of possibility for political ecology as it proliferates in the First World and North America. Let me affirm at the outset that I am not the first to call into question the relation between political ecology and spatiality. Nor am I the first to suggest that political ecology gains from poststructural or Gramscian theory (compare Escobar, 1999; Moore, 1996). Indeed, the research that has already been conducted on political ecology in the Americas suggests that there are complex questions about spatiality and knowledge to consider, as the geographies of the Americas cannot be understood without a careful analysis of colonial practices (Braun, 2002). One lesson from this literature is that political ecology should cultivate an awareness of the multiple, contested natures and spaces of colonized spaces. Elsewhere I have discussed this challenge through a reading of a conflict over the rerouting of a highway through a state park in Minnesota (Wainwright and Robertson, 2003). The conflict came to revolve around a text, a cultural resource assessment, which found that there were no grounds for claims by the Mendota Mdewekanton Dakota for the protection of an area within the park on the basis of federal indigenous or environmental laws. The discourse of the cultural resource assessment produced the effect of an unbroken and homogeneous space-an ahistorical 'Minnesota' - in which the state asserted for itself the terms by which to judge the Dakota claims. If one were to conduct a political ecological analysis of the highway reroute, simply framing the conflict as one 'in Minnesota' would be to concede the most fundamental point of contention, that is, the conception of where the conflict occurred.

The point is that doing political ecology in postcolonial spaces carries the responsibility of engaging with colonialism, because we cannot understand these spaces outside of, prior to, or apart from the fact of the colonial experience. But if, as I will argue, imperialism is fundamental to the very production and organization of the world and our knowledges of it, then this point could conceivably apply to all spaces (minimally this concerns the whole of the First World, if by this we mean the historic centers of capitalist imperialism: Europe, the USA, and Japan). In this view, in order to analyze environmental politics in the colonial present, we need to account for the practices that constitute spaces as such. This is to ask: what is it that produces the 'here' and the 'there' as distinct spaces - each somehow particular, distinctive, and singular?

The conflicts over nature that political ecologists study always already concern the forms of spatiality and worldhood that infuse the very discourses and concepts ('nature', the 'here', 'home', etc) that are contested. I will argue that we should dwell on the ontological presuppositions of the act of specifying our objects of study. I am suggesting that political ecologists should reject a realist approach that assumes that regions and spaces exist in a Cartesian world and are simply there for us to examine. As soon as we define a space or region as our object ('North America'; 'the West'), we stand to lose sight of its becoming. We can forget that the very objectivity of a space is a problem to be explained, and not a scale of analysis to be embraced.

\section{Disorienting political ecology}

Although this argument is abstract, I suggest that it has concrete ramifications for how we do political ecology. I will try to elaborate these through a brief reading of certain texts by Edward Said. I turn to Said for two reasons. The first is that his untimely passing should compel us to reflect on the most effective ways to take up what he called "the struggle over geography." Second, Said's contributions transformed the 
conditions of possibilities for thought across many fields of knowledge, including political ecology. I contend that Said was among the most important geographers of the 20th century - in large part, ironically, because his approach to spatiality is profoundly antidisciplinary. And this approach is part of what makes his work so useful for thinking through the spaces of political ecology.

Said's importance as a geographer-by which I mean his importance as one who produced critical readings of the world-has been widely recognized since the 1978 publication of Orientalism, his rightfully famous study of the histories and effects of orientalist discourses and institutions. It is often said that Orientalism criticizes the West's understanding of the so-called 'Orient'. Yet to leave the argument at that - to note, as did a eulogy in The Guardian, only that Orientalism forces Westerners "to re-examine their perceptions of the Islamic world" (Wright, 2003) - is vastly to understate the originality and implications of his argument. Said's critique of orientalism is arguably the first, and perhaps still the best, demonstration that our ways of understanding the world are produced by discourses and institutions that have histories. His critique of orientalism examines how it is that 'imaginative geographies'-effective representations of the world - are produced by orientalist discourses and disciplinary institutions. Said shows that the production of the Orient is an effect of a disciplinary form of knowledge tied at the root to imperialism. Insofar as the Orient was produced as the result of a suite of historical-geographical practices, its existence cannot be taken as an innocent, pregiven, or objective fact.

Yet, as Said elaborates in numerous books and essays, these imaginative geographies have immense effects long after the end of formal colonialism. The problem is not only that the West has a peculiar way of enframing and orienting the world in which we are bound within an ontologically fixed field of Cartesian space (Heidegger 1996 [1927], Division I, Section III-B). The insidious result is that the imperial way of framing the world contributes towards the reproduction of unequal geographies and the intense divisions between peoples: "The general basis of Orientalist thought is an imaginative and yet drastically polarized geography dividing the world into two unequal parts, the larger, 'different' one called the Orient, the other, also known as 'our' world, called the Occident or the West" (Said, 1981, page 4). There is no way simply to extract our subjectivities from the world and its divisions. Insofar as the geographical orientation of groups of people is identified with particular territorialized nation-states and imagined geographies, the ontological production of the world and subjectivities are joined. Identities and geographies are thus coconstituted. This is not a natural condition. According to Said, it is an effect of imperialism, which required the production of the very distinction between the 'West' and its others.

This point has often been lost on those who see in Said's work only a facile slam on Western or American culture. Consider one of the more astonishingly poor readings of Orientalism, written by Christopher Hitchens for the Atlantic Monthly (2003). Hitchens accuses Said of failing to be "cool and objective" in his assessment of "today's fanaticisms" and suggests that Said's whole approach to the Orient is unbalanced:

"It is easy enough to say that Westerners had long been provided with an exotic, sumptuous, but largely misleading account of the Orient, whether supplied by Benjamin Disraeli's Suez Canal share purchases, the celluloid phantasms of Rudolph Valentino, or the torrid episodes in T. E. Lawrence's Seven Pillars of Wisdom. But it is also true that Arab, Indian, Malay, and Iranian societies can operate on a false if not indeed delusional view of 'the West'."

Hitchens argues that all "cultural - political interaction" is essentially "dialectical", and that Said "chose a one-sided approach" - that is, against the West. Now, anyone who is the least bit familiar with Said's work and his appreciation for figures such as Beethoven 
and Conrad should recognize that Said is not simply trying to turn the tables on the West. The problem is not that the West can do no good, nor that "Arab, Indian, Malay and Iranian" views are simply real or true. Hitchens's reading demonstrates how badly misunderstood Said's arguments remain. Like most critics of Orientalism, he presumes the East - West distinction to be ontologically prior to our knowledge. But the purpose of Said's writings - in Orientalism, Culture and Imperialism (1993), and his many essays on Palestine-is to examine the production of this distinction and its political and cultural effects. Said shows that the problem in cultural analysis is not a question of finding a balanced view of the 'East' from the 'West' or vice versa: it is the very framing of the world in such terms that is misleading.

\section{Gramscian geographies}

In the 1994 afterward to Orientalism, Said suggests that his aim was to extend "postcolonial concerns to the problems of geography ... [and] to challenge the notion that difference implies hostility, a frozen reified set of opposed essences, and a whole adversarial knowledge built out of those things. What I called for in Orientalism was a new way of conceiving the separations and conflicts that had stimulated generations of hostility, war, and imperial control" (1994, page 350). This was not what Said was calling for at the start of his prodigious career as a literary critic. His earliest books - on Joseph Conrad (1966) and the problem of foundations of literary and philosophical study (1975) — do not turn on questions of imperialism, spatiality, and power. What explains the shift of focus between these works and Orientalism in 1978? Said's critique of orientalism emerged while he was struggling to situate the post-1973 crisis in Palestine within the broader history of imperialism. During this period, Said studied Antonio Gramsci's Prison Notebooks. After 1976, Said's texts are infused with references to Gramsci (the earliest I have found are 1976a, page 66, and 1976b, page 21). Said notes the importance of Gramsci's approach to understanding historical and geographical knowledges to his project in the 1978 introduction to Orientalism (pages 6-7, 14, 25-26), where Gramsci's treatment of hegemony is used to explain Orientalism's durability (page 7). Reflecting on this period, Said noted in a 1993 interview that he drew from Gramsci a sensitivity for the ways in which imperial geographies come to be accepted as natural:

"[W] accept it as natural because it is 'natural' geography under those circumstances. By natural, I mean because they're there. ... [T]he main influence on me in all of this is Gramsci. ... [T]his is the single most important thing that I took from Gramsci-not by the idea of hegemony ... but the idea that everything, including civil society to begin with, but really the whole world, is organized according to geography. He thought in geographical terms, and the Prison Notebooks are a kind of map of modernity. They're not a history of modernity, but his notes really try to place everything ... [in the notebooks] there was always some struggle going on over territory (2002 [1993], page 195).

Leaving aside the enigma of how Said interprets the concept of territory in Gramsci's notebooks (a question worthy of its own study), Said's argument raises another question: what led Gramsci to produce such an analysis, a sort of geography of the present? Gramsci's early writings show no particular predisposition towards spatiality. But one can notice a certain shift in his texts from the late 1920s, when Gramsci began to examine the production of hegemony in Italy. Gramsci's spatial emphasis is an effect of the challenge of explaining the production of hegemony in a noneconomistic tenor. Gramsci sought to interpret the reasons that different social groups came to be separated or united as spatial subjects - and how they came to be united by rightwing appeals to national belonging. In his unfinished essay on the "southern question", Gramsci argues that the central problem for Italian communists is to articulate Italy's 
southern peasants with the northern proletariat. Gramsci saw that the communist party could not rely on the shared class interests of different social classes to generate a united front; the links between disparate social groups must be forged through concrete forms of political and intellectual leadership. For Gramsci, the proletariat can only become the hegemonic class "in the measure in which it succeeds in creating a system of class alliances that will permit it to mobilize the majority of the working population against capitalism and the bourgeois state ... [In] the real class relations as they exist in Italy, [this] depends on the measure in which it is successful in obtaining the consensus of the large peasant masses" (1995 [1926], page 19). The "southern question", in short, was how to transform the uneven terrain of knowledge and power on which the peasantry embraced fascism. Producing communist hegemony therefore implies reconfiguring the very spatial basis of political, cultural, and economic life in such a way that the proletariat and peasantry may realize their potential alliance.

Thus, hegemony is doubly geographical: hegemony is constituted on the basis of spatial relations, and such relations become hegemonic as geographies are naturalized and sedimented as common sense through political and cultural practices. In one of his prison notebooks, Gramsci discusses the problem of the naturalization of spatial relations as part of a discussion on the "so-called reality of the real world":

"In order to understand exactly the possible significance of the problem of the reality of the external world, it may be useful to develop the example of the notions of 'East' and 'West' which do not stop being 'objectively real' even if on analysis they prove to be nothing but conventions, i.e. 'historico-cultural constructions'. ... It is evident that East and West are arbitrary, conventional, i.e. historical, constructions, because outside real history any point on the earth is East and West at the same time. We can see this more clearly from the fact that these terms have been crystallized not from the point of view of man in general but from the point of view of the cultured European classes who, through their world hegemony, have made the terms evolved by themselves accepted everywhere" (1991 [1957], pages 108-109).

Note that the claim is emphatically not that the real world does not exist. Gramsci accepts, of course, that East and West stand in a material relation to the diurnal rotation of the Earth vis-à-vis the sun. But even these celestial relations are always already received through signs that make sense only through geographies that reflect the hegemony of "the cultured European classes". The broader point is that there are no geographical concepts, terms, or metrics-including territory, scale, nature, or place - that stand outside of language, history, and politics. And therefore questions about exactly where some thing is, or what a space is, can only be perpetually negotiated, deferred, and contested. In this sense, Gramsci's expression "world hegemony" has a double meaning: in producing colonial hegemony on a global scale, the West reproduces a hegemonic worldhood.

Orientalism is arguably the strongest working-through of this argument yet written. Said developed what Gramsci could not: a careful, almost encyclopedic genealogy of the traces that have produced one of the most pervasive and important "arbitrary, conventional, i.e. historical, constructions" ever materialized through European imperial cultural practices. Said pursued this work in a historicist and humanist spirit that is implicit in Gramsci's argument - that our aim should be to build a "point of view of man in general". Pace Said, I would argue that this position is incompatible with a more radical postcolonial position that can be drawn from Gramsci's claim about the fundamental arbitrariness of the signs of the world. There are no spaces in which the humanist can see the world 'in general". The implication is that, rather than doing political ecology from a point of view of 'man in general' - from a humanist view from nowhere (Haraway, 1996) - I argue that we should take apart the practices that stabilize 
the singular worldhood of the modern world. This implies a perpetual unsettling and destructuring of the knowledges that reproduce the distinctions between Europe and its others. Although this is clearly not the reading that Said pursues, it is not inconsistent with the Gramscian conceptual repertoire. As Said argues:

"[M]ost of Gramsci's terminology-hegemony, social territory, ensembles of relationship, intellectuals, civil and political society, emergent and traditional classes, territories, regions, domains, historical blocs - is what I would call a critical and geographical rather than an encyclopedic or totalizing nominative or systemative terminology. The terms slide over rather than fix on what they talk about; they illuminate and make possible elaborations and connections, rather than holding down, reifying, fetishizing. ... The basic social contest for Gramsci is the one over hegemony, that is, the control of essentially heterogeneous, discontinuous, nonidentical, and unequal geographies of human habitation and effort" (2002 [1995], pages $467-468)$.

Seen in this light, Said's critique of orientalism is an extended Gramscian analysis of the practices through which large numbers of people become geographically and politically oriented. Orientalism produces 'the Orient' as an object for description while simultaneously disciplining knowledges about this object to conform to a particular way of reading. Thus, 'the Orient' is produced as a contained place, a bounded region set within the real world, with a specific form of external and expert knowledge appropriate to it. Like the disciplines that divide the world of knowledge, the world of orientalism is subpartitioned into pieces that stand opposite one another.

Apart from the aforementioned question of humanist metaphysics, there are important limits and exclusions in Said's reading of Gramsci. To my knowledge, Said never dwells on Gramsci's communism, his novel approach to the state, or his strategies for achieving proletarian hegemony. Nor do Said's writings on Gramsci's 'social groups' address the fact that, for Gramsci, understanding the existence and transformations of such groups requires a Marxist theory of class. ${ }^{(1)}$ These lacunae-which, taken together, reflect a willfully non-Marxist reading of the notebooks - are simply astonishing, given that it is precisely around these themes that Gramsci's thought gravitates. As I have argued, it was the challenge of producing communist hegemony that propelled Gramsci to think through the relations between spatiality, power, and cultural practices in such an original and forceful way. Through his reading of Gramsci, Said gleans a conceptual repertoire for interpreting spatiality, imperialism, and powerwithout squarely addressing the question of capitalism at the heart of the notebooks. This lacuna has contributed to the distance between postcolonial and Marxist approaches to imperialism and capitalism and has yet to be adequately addressed (although see Spivak, 1999).

Perhaps the partialness of Said's reading should not come as a surprise, because his turn to Gramsci was inspired by the struggle for Palestinian sovereignty and not an interest in Marxist theory per se. Said's texts are never so densely filled with spatial metaphors and a Gramscian tone as when he addresses the problem of the (mis)recognition of the existence of Palestine. His argument for secular, humanist, geographically

(1) Said's hermeneutics of the notebooks are outlined in "History, literature, and geography" (2002 [1995]), in which he argues that five themes are essential to interpreting the notebooks: (1) the interconnection between political power and cultural life; (2) the opposition to determinism and economism; (3) the articulation of ideas and cultural practices with specific social classes; (4) the undermining of the theory-practice distinction; and (5) the intensely geographical tone. Of these, Said suggests that the last is the most profound, because it is Gramsci's "spatial sense of discontinuity that complicates and renders far less effective ... the possibility of correspondence, congruence, continuity, and reconciliation between different areas of experience" (page 458). What is striking is that Gramsci's debts to Marx and his Leninist politics are not cited as primary guidepoints. 
attentive strategies to resist both Zionism and narrow forms of nationalism made him a fierce critic of the Palestine Liberation Organization (PLO) leadership. Never one to put solidarity before criticism, Said left the Palestinian government in exile in 1991 after criticizing Yasser Arafat's willingness to capitulate to Israeli and US forces (for his criticisms of the Oslo process, see Said, 1996). After the Oslo accords were signed, no critic more profoundly anticipated its disastrous effects for the Palestinians. In an essay written shortly after Oslo, Said criticized the PLO for its lack of preparations in the struggle over geography:

"In the history of colonial invasion maps are always first drawn by the victors, since maps are instruments of conquest. Geography is therefore the art of war but can also be the art of resistance if there is a counter-map and a counter-strategy. ... The Arab technique has always been to make very large general assertions and then hope that the concrete details will be worked out later. Thus the PLO accepted the Oslo Declaration of Principles on the grounds that Palestinian autonomy would somehow lead to independence if enough rhetorical statements about an independent Palestinian state were made; but when it came to negotiating the details ... we had neither the plans nor the actual details. They had the plans, the territory, the maps, the settlements, the roads: we have the wish for autonomy and Israeli withdrawal, with no details, and no power to change anything very much. Needed: a discipline of detail (1996 [1993], page 27).

This statement reflects one of the Gramscian tones that pervade Said's work. Here and elsewhere we find an intense strategic vision focused on the task of producing positions and forms of knowledge capable of reconstituting sociospatial relations. In these works, Said never strays from a commitment to understanding "the facts on the ground." But this commitment to these facts, like his nationalism, never led Said to dodge the critical, theoretical task of examining the cultural processes, texts, and histories that produced 'the facts' as such. His texts never settle for a fixed notion of what the world was-or could become.

\section{Political ecology after Said}

It is this Gramscian geographical spirit to which, I argue, political ecology should aspire. To return to the questions that opened this essay, it strikes me that the shift towards First World political ecology calls for us to think about the spaces of political ecology - that is, to consider how we are to speak of, understand, and read the spaces 'in' which environmental conflicts unfold. This is why we should hesitate before deploying political ecology from one place to another: simply transposing a research framework presupposes that spaces are distributed before our knowledge in an unproblematic way. The act of thematizing such research qua First World, or 'North American', etc, threatens to short-circuit our most urgent path of inquiry-namely, into the ways that conflicts over nature always already entail struggles over the constitution of the world and its spaces.

I do not mean to overstate Said's singularity. Many anticolonial critics raised similar arguments, as Said was wont to note. Valentin Mudimbe, for instance, teaches a similar lesson through his archaeological readings of African ways of knowing in The Invention of Africa (1988). The point of the text is not to suggest that Africa does not really exist, but rather to inquire into the conditions of possibility of 'African thought', and at the same time, the thought of Africa. Mudimbe prosecutes this project through a Foucaultian reading of the "foundations of discourse[s] about Africa" in ethnography, ethnohistory, and philosophy. Similarly, Santiago Castro-Gómez (2003) has called for a critical ontology of the Latin American present. Such an ontological investigation would entail writing genealogies of those disciplines that "have produced 
both [Latin American] reason" (page 72) and would elucidate the forms of power and knowledge out of which "an object of knowledge called 'Latin American' was discursively produced” (page 73).

These projects reflect departures from a kind of critical realist, regional framework that implicitly shapes most political ecology research. But, to borrow a trope from Robbins, there is nothing epistemological or methodological that would appear to prevent Said's, Mudimbe's or Castro-Gómez's mode of analysis from inclusion in the political ecology toolkit. There is nothing to prevent a political ecology that considers the spatial-ontological ground of geographical knowledge.

To offer concrete illustrations of work that, to my mind, accomplishes this sort of postcolonial rethinking of spaces, nature, and power, I want briefly to cite two books: Hugh Raffles's In Amazonia (2002) and Derek Gregory's The Colonial Present (2004). Raffles's study is exemplary as a kind of natural history of the Amazonian present (page 7), that is, a genealogy of the nature of spaces in Amazonia and also an interrogation of the spacing of nature as it has become 'Amazonian'. Such a project does not lend itself well to disciplinary or methodological confines, and In Amazonia does not read like an ordinary study in anthropology, geography, or political ecology. This antidisciplinary style, which is one of the book's greatest strengths, is solicited by the problematic that guides the readings: "The natures I describe in this book are dynamic and heterogeneous, formed again and again from presences that are cultural, historical, biological, geographical, political, physical, aesthetic, and social" (page 7). Only an analysis that attends to each of these categories - and their excesses - could do justice to such natures. Following Said, Raffles notes that his treatment of nature requires accounting for the "sedimented histories ... that have circulated and multiplied ever since Europeans first came here in the sixteenth century, situated their geographical imaginations, and returned home with wide-eyed accounts of their adventures" (page 6). In light of these sedimented histories, there is no way to interpret the nature of Amazonia, or Amazonia's nature, without tracing the ways that generations of European visitors "have struggled to locate new experiences on old intellectual maps, returning again and again to discover the region, as if for the first time" (page 6).

Raffles does not offer himself as one more European who has come to discover the truth about Amazonia. Rather, he positions himself as one trying to do justice to its particularity while deconstructing this reiterated colonial trope about the space. The originality and strength of the text lies in the rigor with which Raffles struggles through the aporias manifest in both thinking through and writing on the problematic of 'Amazonia'. As Raffles modestly observes: "It is difficult to write densely constituted worlds filled with things that can, without naïvité or reductionism, be termed nature" (page 7). Unlike most political ecology, which narrates a story of the political ecology of such-and-so region, his way through this problem is to produce a natural history of the present that stands open to the multiplicity and unboundedness of 'Amazonia'. Here is how Raffles explains it:

"Such nature calls for a natural history, and articulation of natures and histories that works across and against spatial and temporal scale to bring people, places, and the non-human into 'our space' of the present. This is less a history of nature than a way of writing the present as a condensation of multiple natures and their differences" (page 7).

Different chapters of In Amazonia trace out some of the fragments of this articulated present: a creek that becomes a river; Sir Walter Ralegh; a butterfly collection; migrating communities; etc. None is presented as the master key that opens the door to the truth of Amazonia. Similarly, the plethora of maps and images in the text aid in 
appreciating this complex "condensation of multiple natures", without ever suggesting that the map of Amazonia settles the matter of what or where Amazonia really is.

In a very different way, Gregory's book (2004) offers a second illustration of how political ecology could take up Said's call for Gramscian geographies. Much of the text is comprised of a rigorously polemical attack on US imperial aggression and the particular spacings through which it is constituted. His approach, which is deeply inspired by Said (though Agamben provides Gregory's sharpest theoretical tools), is to loosen up and take apart the imaginary geographies that reproduce the colonial present. Gregory's focus is on the performative work of an imperial spacing and its performative violence across a sutured and uneven terrain of space and power (and not 'a region'). The text is organized through a "triptych of studies" - of the geographies of violence towards Afghanistan, Palestine, and Iraq- "that narrate the war on terror as a series of spatial stories that take place in other parts of the world" (page 13). The point is not simply to show how these 'other spaces' are unfairly treated but to rewrite "these spatial stories and their contrapuntal filiations" (page 20) in order to call into question the very "banality of the colonial present" (page 15).

What makes The Colonial Present important for political ecology is not simply that it provides a radical political critique of US state power, which has clear enough links to ecological issues. Rather, what sets it apart from many other critiques of US foreign policies [such as Noam Chomsky (2003)], and what makes it so important at this juncture, is that the text makes the very production, representation, and enframing of the spaces in which imperial violence works the essence of the analysis. The Colonial Present is not so much a critique of US policy towards three countries as it is an investigation of a form imperial power that works in and through a set of spacings that separate, delimit, and violently set peoples and places against one another. This project inevitably presents aporias of writing (for how do we refer to spaces we are simultaneously trying to call into question?) that Gregory struggles through with admirable rigor. Consider:

"I follow the standard convention of using 'America,' 'Israel', and 'Britain,' 'Afghanistan', 'Palestine,' and 'Iraq' as shorthand expressions. In fact they are of course cover terms for complex networks that spiral through state and para-state, military and para-military apparatuses. ... The networks spiral beyond those apparatuses. To be sure, there are political differences and divisions within each of [these] cover terms .... None of them is monolithic, and [my aim is] to reveal just what it is that they cover" (page 29).

This is, I would argue, an elaboration of the Gramscian geographical purview, one that aims to disorient the hegemonic spacings that set the USA against the Orient in an unceasing clash of civilizations.

But one may ask: are these studies in, or of, political ecology? They do not claim to be. And insofar as they do not examine environmental conflicts within a framework informed by political economy ${ }^{(2)}$, cultural ecology, and ecology, the answer is no. Yet I would argue that they both accomplish what is most essential to political ecology, understood not as a research framework, but as an antidisciplinary project: they call into question the constitution of the world as such — its spacing - in ways that allow us to think radically about the politics of nature.

(2) Said's deemphasis of Marxism is paralleled in these two books, in which the histories of capital circulation and accumulation do not weigh heavily. In this sense, Raffles's text could be read in counterpoint with Susanna Hecht and Alexander Cockburn's Fate of the Forest (1989), and Gregory's alongside David Harvey's The New Imperialism (2003). 


\section{Conclusions}

"The terrible conflicts that herd people under falsely unifying rubrics like 'America', 'the West', or 'Islam' and invent collective identities for large numbers of individuals who are actually quite diverse, cannot remain as potent as they are and must be opposed."

Edward Said (2003)

Said's critique of the potency of rubrics such as 'America" and 'the West' suggests the danger of equating a shift in geographical focus with the creation of new concepts. Rather than deploy political ecology from one "falsely unifying rubric" to another, I have tried to argue that we should try to explain how these spaces come to be construed as such. If political ecologists describe environmental conflicts as events that happen in discrete places that are defined in advance (for example, 'North America'; 'the West'), we stand to miss what is arguably most radically political about political ecology: its intention to read the ways that the world is reproduced through environmental conflict.

Said refused the assertion that somehow we could take hold of the world without actually reading contrapuntally, that is, without applying a critical and syncopated scrutiny to the practices and texts that produce the world for us as something to behold. In this way, geography never entails merely describing the world: it is instead a political, hermeneutic practice of reading and writing worlds. Twenty-five years ago Said suggested that we take "Vico's great observation that men make their own history ... and extend it to geography" (1978, page 5). The current state of divisive, imperial global geographies suggests that our work in critically elaborating the ways in which our geographies have been produced is far from complete. Nothing could be more urgent than the task of unsettling the presuppositions about the naturalness of the geography of our unjust and violently divided world. Said's life and work suggest ways to carry the struggle forward.

Acknowledgements. I thank James McCarthy, Kristin Mercer, Jamie Peck, Morgan Robertson, and three anonymous reviewers for their comments on an earlier draft. The usual disclaimer applies.

\section{References}

Blaikie P, Brookfield H (Eds), 1987 Land Degradation and Society (Methuen, New York)

Braun B, 2002 The Intemperate Rainforest (University of Minnesota Press, Minneapolis, MN)

Bryant R, 1997 Third World Political Ecology (Routledge, New York)

Castro-Gómez S, 2003, "Latin American philosophy as critical ontology of the present: themes and motifs for a 'critique of Latin American reason'" Latin America and Postmodernity: A Contemporary Reader Eds P Lange-Churion, E Mendieta (Humanity Books, Amherst, NY) pp $68-79$

Chomsky N, 2003 Hegemony or Survival: America's Quest for Global Dominance (Metropolitan Books, New York)

Davis M, 2003 Dead Cities: And Other Tales (New Press, New York)

Escobar A, 1999, "After nature: steps to an anti-essentialist political ecology" Current Anthropology 40(1) $1-30$

Gramsci A, 1991 [1957] The Modern Prince and Other Writings (International Publishers, New York)

Gramsci A, 1995 [1926] The Southern Question translated by P Verdicchio (Bordighera, West Lafayette, IN)

Gregory D, 2004 The Colonial Present: Afghanistan, Palestine, Iraq (Blackwell, Malden, MA)

Haraway D, 1996, "Situated knowledges: the science question in feminism and the privilege of partial perspective", in Human Geography: An Essential Anthology Eds J Agnew, D Livingstone, A Rogers (Blackwell, Oxford) pp $108-128$

Harvey D, 2003 The New Imperialism (Oxford University Press, New York)

Hecht S, Cockburn A, 1989 The Fate of the Forest: Developers, Destroyers, and Defenders of the Amazon (Verso, New York)

Heidegger M, 1996 [1927] Being and Time (State University of New York Press, Albany, NY)

Hitchens C, 2003, "Where the twain should have met" Atlantic Monthly 292(2) 153-159 
McCarthy J, 2001, "Environmental enclosures and the state of nature in the American West", in Violent Environments Eds N Peluso, M Watts (Cornell University Press, Ithaca, NY) pp 117 - 145

McCarthy J, 2002, "First world political ecology: lessons from the Wise Use movement" Environment and Planning A 341281 - 1302

Moore D, 1996, "Marxism, culture, and political ecology: environmental struggles in Zimbabwe's Eastern Highlands", in Liberation Ecologies: Environment, Development, Social Movements Eds R Peet, M Watts (Routledge, London) pp 125-147

Mudimbe V Y, 1988, The Invention of Africa: Gnosis, Philosophy, and the Order of Knowledge (Indiana University Press, Bloomington, IN)

Prudham W S, 2003, "Taming trees: capital, science, and nature in Pacific Slope tree improvement" Annals of the Association of American Geographers 93 636-656

Prudham W S, 2004, "Poisoning the well: neo-liberalism and the contamination of municipal water in Walkerton, Ontario" Geoforum 35343 - 359

Raffles H, 2002, In Amazonia (Princeton University Press, Princeton, NJ)

Robbins P, 2002, "Letter to the editor. Obstacles to a First World political ecology? Looking near without looking up" Environment and Planning A 34 1509-1513

Robbins P, Sharp J, 2003a, "The lawn chemical economy and its discontents" Antipode 35955 - 979

Robbins P, Sharp J, 2003b, "Producing and consuming chemicals: the moral economy of the American lawn" Economic Geography $79425-451$

Robertson M, 2000, "No net loss: wetland restoration and the incomplete capitalization of nature" Antipode $32463-493$

Robertson M, 2004, "The neoliberalization of ecosystem services: wetland mitigation banking and problems in environmental governance" Geoforum 35361 - 373

Said E, 1966 Joseph Conrad and the Fiction of Autobiography (Harvard University Press, Cambridge, MA)

Said E, 1975 Beginnings: Intention and Method (Basic Books, New York)

Said E, 1976a, "Between chance and determinism: Lukács' Aesthetik" Times Literary Supplement 6 February, reprinted in E Said, 2002 Reflections on Exile (Harvard University Press, Cambridge, MA), pp $61-69$

Said E, 1976b, "Beginnings: interview with Edward Said" Diacritics 6(3), reprinted in E Said, 2001 Power, Politics, and Culture: Interviews with Edward Said Ed. G Viswanathan (Random House, New York) pp $3-38$

Said E, 1978 Orientalism (Vintage, New York)

Said E, 1981 Covering Islam: How the Media and the Experts Determine How We See the Rest of the World (Pantheon, New York)

Said E, 1994 [1993] Culture and Imperialism (Vintage, New York)

Said E, 1994 Representations of the Intellectual: The 1993 Reith Lectures (Pantheon, New York)

Said E, 1996 [1993], "Facts, facts, and more facts", in Peace and Its Discontents: Essays on Palestine in the Middle East Peace Process (Vintage, New York) pp 26-31

Said E, 2002 [1993], "Culture and imperialism: an interview with J. Buttigieg and P. Bové”, in Power, Politics, and Culture (Vintage, New York) pp 183-207

Said E, 2002 [1995], "History, literature, and geography", in Reflections on Exile (Harvard University Press, Cambridge, MA) pp $453-473$

Said E, 2003, "Orientalism 25 years later: worldly humanism v. the empire-builders", http://www.counterpunch.org/said08052003.html

Wainwright J, 2004 Decolonizing Development: Mayanism, Agriculture, and Colonialism in Southern Belize PhD dissertation, Department of Geography, University of Minnesota, Minneapolis, MN)

Wainwright J, Robertson M, 2003, "Territorialization, science, and the postcolonial state: the case of Highway 55 in Minneapolis, USA" Cultural Geographies 10 197-217

Wilson R, 1999, “'Placing nature': the politics of collaboration and representation in the struggle for La Sierra in San Luis, Colorado" Ecumene 6(1) 122-128

Wright G, 2003, "World-renowned scholar Edward Said dies" The Guardian 25 September 
